\title{
赤血球溶血液の電気泳動的研究
}

\section{一正常各種動物赤血球について -}

\author{
京都大学医学部內科学数室
}

（担当 前川孫二郎教授）

\section{Electrophoretic Studies on Red Blood Cell Hemolystates} \\ (On various Kinds of Normal Animals' Erythrocȳtes) \\ Teruo Nakazawa \\ (Department of Medical Faculty of Kyoto University, Director, Prof. M. Maekawa)
}

中 沢 輝 郎

Electrophoretic experiments of red blood cell hemolystates weve carried out on many kinds of normal animals mammalls (human, rabbit, goat), aves (cock), reptilia (snake), ámphilia (toad), and pisces (crucian).

Results obtained are as follows.

1) About $\mathrm{Hb}$ peak

Electrophoretic patterns of human, rabbit, snake and crucian red blood cell hemolysates resembled in shape with each other, but differd in mobility. Characteristic was the fact that Hb peak of cock divided into three parts and that of goat had a special knot.

The knot in $\mathrm{Hb}$ peak on another patterns seemed to indicate the degenaration or the difference in the nature of erythrocytes.

2) About a-component

In all examples difference in the mobility of a-component was accompained by that in the nature of the cell membrane.

3) About c-component

It was remarkable on goat and crucian, but there this peak was not nothing recognized in other kinds of animals.

4) About b-component

It is remarkable that this peak was found only in human.

\section{I. 緒言}

著者は，前川教授1,2) の提唱による細胞燐脂質を以て する組識アレルギーの研究の一端として, Erythron-allergy (前川 $\left.{ }^{3}\right)$ の抗体を研究するために, 赤血球溶血液 の電気泳動的研究を行つている。被検数が多くなるにつ れて，へモグロビン ( $\mathrm{Hb}$ ) 峰に生ずる結節等不明の点 が多く，種属によつて可成りの相違がある様に思わたの で，基礎実験として無処置の各種属赤血球一一哺乳類 (人間, 山羊, 家鬼), 鳥類, (雞), 爬虫類 (青大将へ び) 両棲類 (がま), 魚類 (ふな)一一溶血液を電気
泳動した。

\section{II. 実験材料及び実験方法}

実験に使用した赤血球は，健康人 3 例（20才，30才， 40才の自覚症なく, 他覚的に健康と思われる男子), 山 羊 2 例 (雄性成熟), 家鬼 3 例 (白色雄性成熟), 雞 3 例 （名古屋コーチン 2 例, 白色レグホン 1 例, いづれも雄 性成熟), 青大将へび (冬眠中にして全長約 1 米) があ 1 例 (冬眠中にして雄性成熟)，ふな 1 例 (1 匹体重 150 瓦位のものから採血し 5 西分を混ず）である。

採血方法, 赤血球処理方法, 電気泳動条件等は, すべ 
て前川, 熊谷, 荒木, 中沢の方法4で行つた。

\section{III. 実 験 成 績}

赤血球溶血液の電気泳動図の基本型は，Stern ${ }^{5}$ ：の命 名にもとづいて，著者)が既に報告した如く，最も大き な峰はへモグロビンである。最も早い速度を有し, 乳白 色の分屑が a 蛋白, Hb より遅い峰が $\mathrm{b}$ 蛋白である。 へモグロビンと a 蛋白との丁度中間の峰が c 蛋白であ る。

\section{1. 健康人赤血球 3 例}

$\mathrm{a}$ 蛋白いら゙れも著明, $\mathrm{c}$ 蛋白著明でない。 Hb 峰の後 脚に結節を認める事が多い。 $\mathrm{b}$ 蛋白は著明である(第 1 図)。1 例の易動度は, 第 1 表の如 $<$, a 蛋白, $\mathrm{Hb}$ 蛋 白, $\mathrm{b}$ 蛋白夫々 $-6.89,-2.05,-1.43 \times 10^{-5} \mathrm{~cm}^{2} \mathrm{volt}^{-1} \mathrm{sec}^{-1}$ （以下単位を省略する）である。

2. 山羊赤血球 2 例; 一

a 蛋白著明， b 蛋白著明でない。 Hb 峰に結節を認め ない。 $\mathrm{c}$ 蛋白は著明である。(第1図)

\section{3. 家鬼赤血球 3 例;}

$a$ 蛋白著明で， $b$ 蛋白なく，且つ $c$ 蛋白著明でない。 （第 1 図） a 蛋白, $\mathrm{Hb}$ 峰の易動度は, 夫々 $-5.83,-1.57$ ， である。(第1表)

4. 雉赤血球 3 例; 一

$a$ 蛋白著明である。 b 蛋白認めず。 Hb 峰が三分する のが特徽的である（第1 1 図:) 易動度は䌖の種類により可成り相違し, 名古屋コーチン では, 夫々 $-4.50,-2.37,-1.50,-0.75$ 妓び $-4.55,-2.18$ $-1.27,-0.67$ である。また，白色レグホンでは -7.17 , $-1.70,-0.97,-0.45$ である。.(第 1 表)

5. 青大将へび 1 例; 一

a 蛋白著明であるるb 蛋白, c 蛋白認めず。 Hb 峰に 結節めり（第1図）。a 蛋白, Hb 峰の易動度は, 夫々,
$-6.42,-0.98$ である。(第】表)

6. がま 1 例; 一

a 蛋白不焦明である。 b 蛋白, $\mathrm{c}$ 蛋白共に認めぬ。Hb 下降脚で結節出り (第 1 図)。 $\mathrm{Hb}$ 結節, $\mathrm{Hb}$ 峰の易動 度は，夫々， $-2.15,-1.62$ である。(第1表)

7. ふな 1 例;

$a$ 蛋白著明である。 $b$ 蛋白認めず。 $c$ 蛋白は特に著明 である。Hb 峰に結節なし。(第 1 図) a 蛋白, c 蛋白, $\mathrm{Hb}$ 峰の易動度は, $-8.95,-5.20,-1.30$ である。

\section{IV. 考按}

一般に赤血球は，哺乳類では，円形で核がなく，哺孚し 類以外の脊椎動物のそれは㫮有核にして且つ棈円であ る。

形態学的には, 従来動物の赤血球に就いては多くの報 告があるが，Werzberg6) は，両棲類，爬虫類，魚類に ついて，その細胞及び核の染色性の相違をまた，

Alder \& Huber ${ }^{7}$ は, 両棲類と爬虫類の赤血球の染色

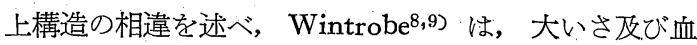
液 $100 \mathrm{cc}$ 中の $\mathrm{Hb}$ 瓦数の相違を報告し, 本邦に於ては, 沼野井 ${ }^{10}$ は，動物の赤血球の大いさと赤血球数とは大体 反比例をなすが，その相乗積は一定に近く，これよりそ の機能も恒状に近いという。

化学的には, Ponder $1,2,5$ は各種動物の赤血球につ いて, 種々の相違, 就中, ghost の組成, 全 Lipid の濃 度, $\mathrm{Hb}$ の濃度の相違を報告している。

著者の実施せる実験成績をみても明らかな如く，主た る形は共通なものが認められるが，最も特異なことは，

$\mathrm{Hb}$ 峰に於て雉のそれが三分することであり，これは恐 らく酸素分圧の最も大きく变化する環境に生活する鳥類 の特徽であると考えられる。Stern はHb 峰を二分し それより早い峰を $\mathrm{c}$ 蛋白とし, その易動度は -5.60 で

第 1 表 正常各種動物の赤血球溶血液の易動度

( $\mathrm{pH} 8.03$ イオン強度 0.1 燐酸緩衡液に於て)

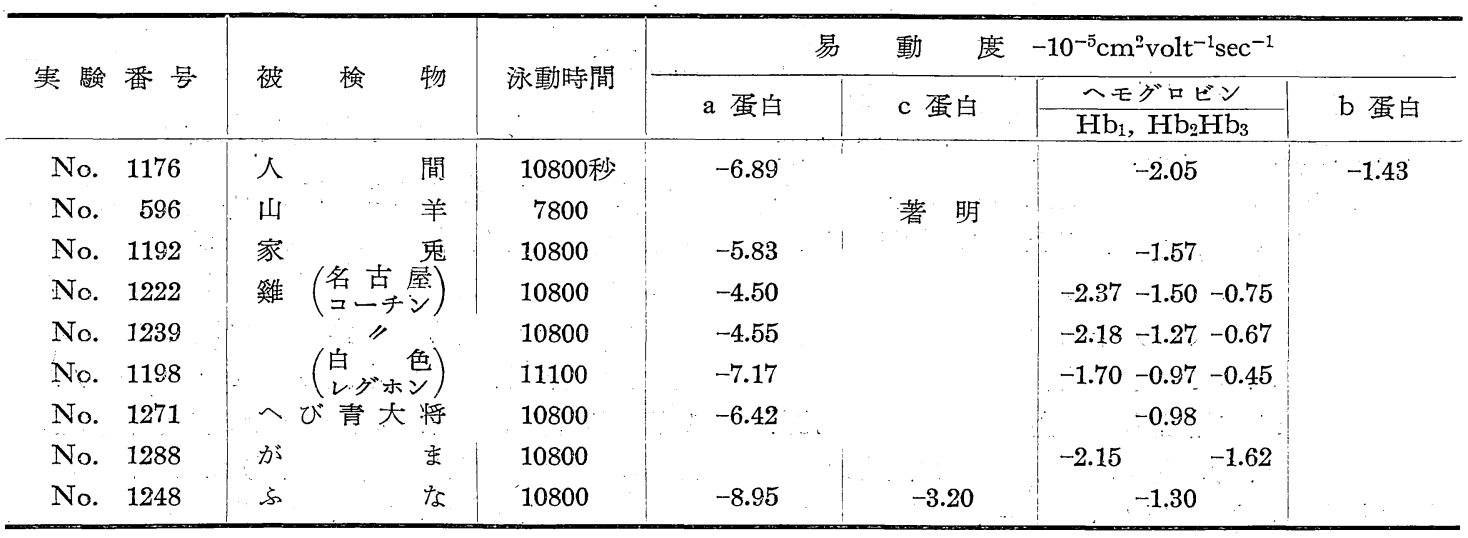



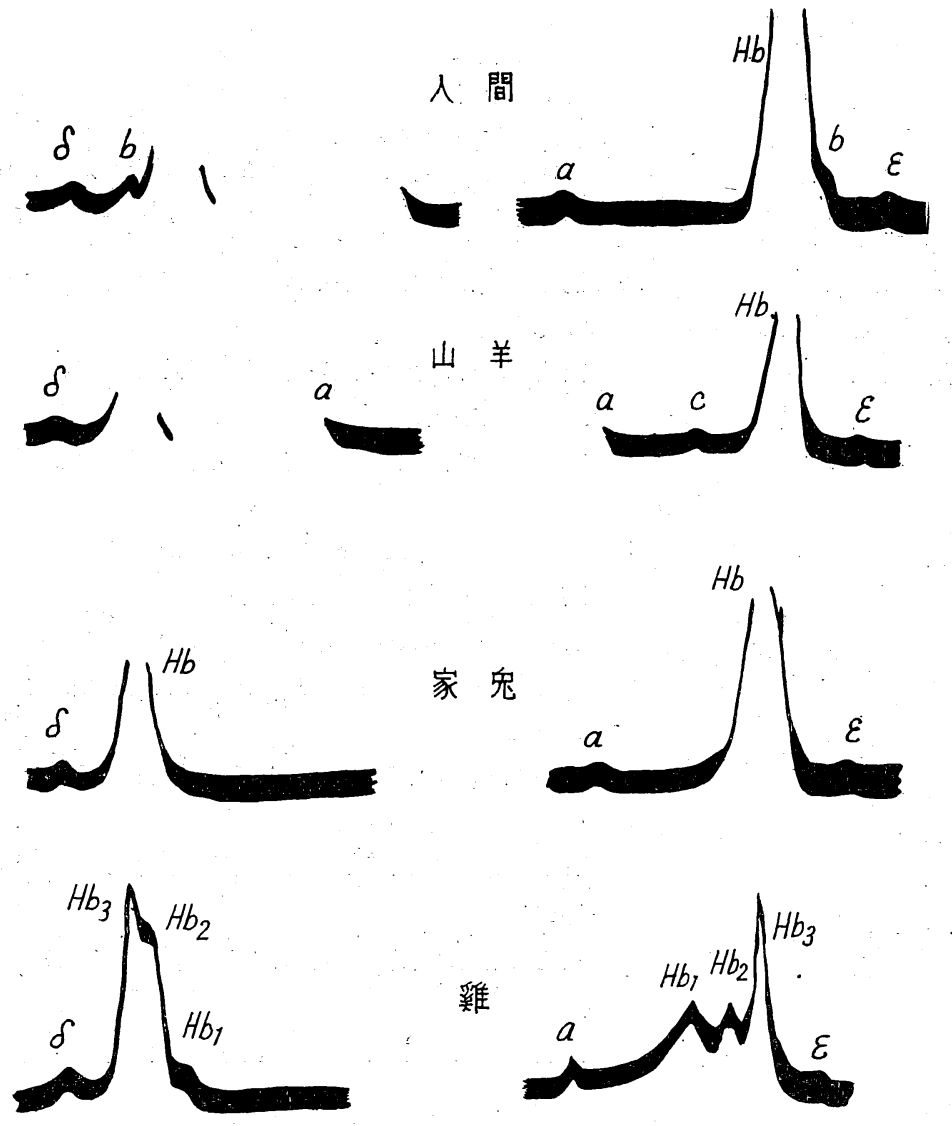

彩
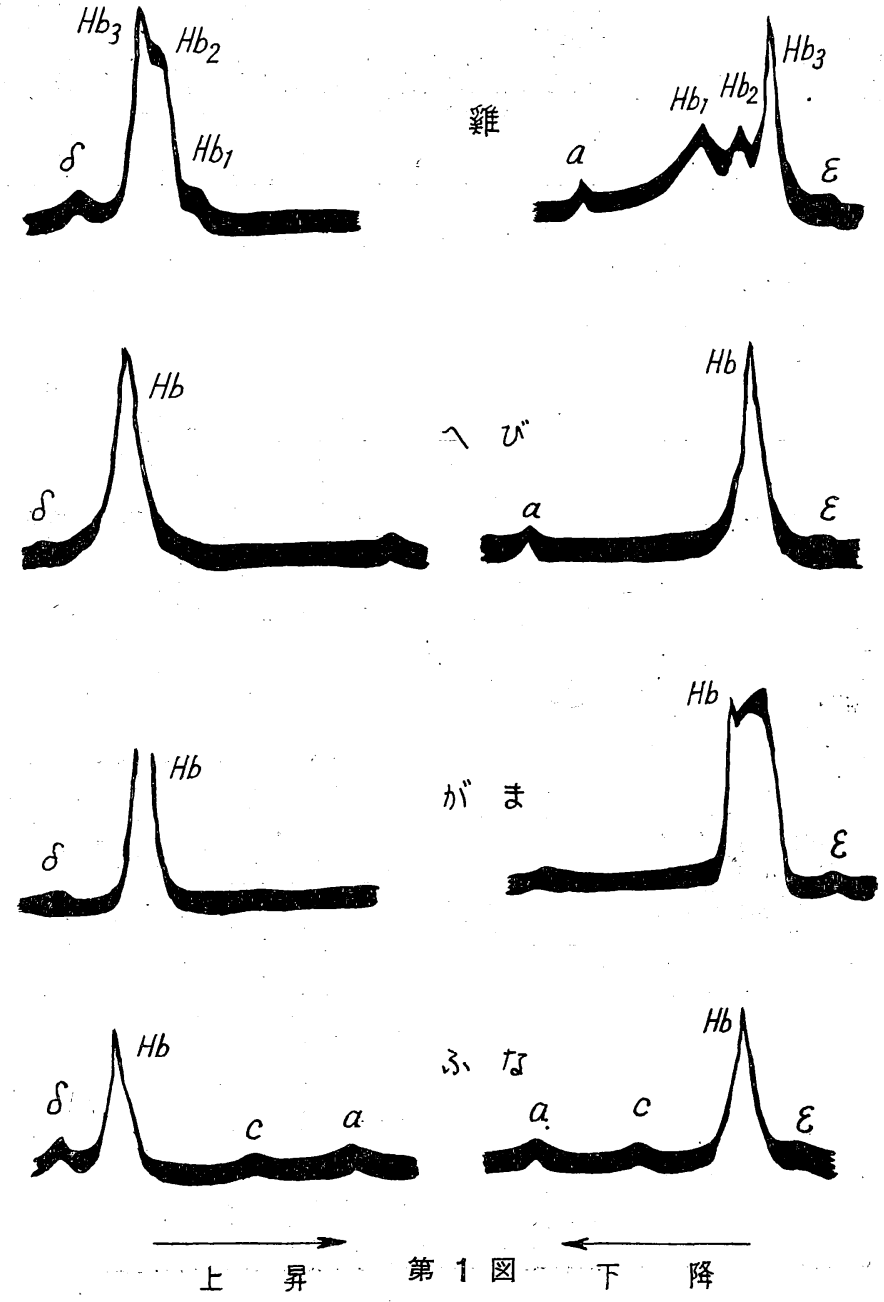

(277)

あり, $\mathrm{Hb}$ 峰のそれは夫々 $-3.50,2.79$ としているのであるが，著者等》の実 施せる実験による易動度 (第1表).か らして，Hb 峰と考学た方がよいと思 われる。

$\mathrm{Hb}$ 峰の易動度は, がま赤血球最も 早人，以下，人間，䌖，家鬼，心な， へびの順になつたががまでは，Hb 峰の先端に他の種属とは異なる一つす 結節が認められるが，他の種属には著 明でない樣に思われる。著者等》は， かつて溶血赤血球を夏季室温汇放置し て変性させ，その $\mathrm{Hb}$ 峰が明らかに二 分するのを認めたが，各種属赤血球が 形態学的にも異り, またへモグロビン 中のグロビンが質量共に相違すること によつて，電気泳動的にも賽るので女 ろら。

また，人間では， b 蛋白が著明に認 められるのも, Ponder によれば ghost の組成中，Hb が他種属の倍以上含有 されていることもその一因となるであ ろう。

c 蛋白に於ては山羊，ふなに著明で あり，他の種属には全く認められない か，殆ど認められない。 Ponder ${ }^{129}$ に よれば, 各種属の ghost の組成に於 て, Lipid の量は, 山羊, ふな最子多 く, 以下，実鬼，人間, 雉の順で岕る。 また，著者等けがエーテル附加によつ て大部分除去されるのをみてより，c 蛋白は類脂体を多く含むことより，こ の Lipidの量によつて相違するのが 原因と考兄られる。

末た，現在著者が行うている赤血球 溶血液電気泳動図は，多くのストロー マが除去されているので；泳動図その ものが，正確に赤血球の含有成分全部 を表現しているものではない。その点 今後改良の余地が充分にあると思われ る。

\section{V. 総 括}

著者は, 正常各種動物赤血球, 即ち 哺乳類 (人間, 山羊, 家鬼), 鳥類 (雞), 爬虫類（青大将へび），両棲類(がま）， 
魚類（ふな）の赤血球溶血液を電気泳動し, $\mathrm{a}, \mathrm{c}, \mathrm{Hb}, \mathrm{b}$ 蛋白に就いて次の結論を得た。

\section{Hb 峰}

人間，実鬼，山羊，へび，らなの赤血球では易動度に 夫々差があるも大体形は似ている。しかし，雞の赤血球 では明らが三分し，が李の赤血球では特別の結節が認 められるのが特徴的である。その他各種属を通じて一般 にみられる $\mathrm{Hb}$ 峰の結節は, $\mathrm{Hb}$ の变性か, 或は多種 性を示すものと思われる。

\section{2. $\quad \mathrm{a}$ 蛋白}

細胞膜が異る限り全例に於て易動度を異にする。

\section{3. c 蛋白}

山羊，ふな赤血球には著明に認められるもその他の種 属には認められない。

\section{4. b 蛋白}

人間赤血球にのみ認められるのが特徵的である。 本論交要旨は昭和27年度第14回日本血液学会に発表し た。

終りに御校閲御指導を賜つた前川教授に深謝しまた 御指導して下さつた荒木博士，御授助下さつた岡田学士 に感謝する。

\section{文献}

1）前川孫二郎：臨床内科小児科 2,1 (昭 22)；血液 討議会報告第 1 輯, p. 203 , 最新医学社, 大阪 (1
948 ); 診断と治療，36,91 (昭23); 日本内科学会 杂倠誌, 38, 177 (昭 24); 同誌, 39, 133 (昭25); 同 誌, 40,242 (昭 26 ); 日本臨床, 8 (1), 5 (昭 25); 同誌, 9 (4), 69 (昭26)

2) 鶴津正, 他: 日本循環器学誌, 11,77 (昭22); 12, 79 (昭 23$)$

3）前川孫二郎, 他：日本内科学会雑誌，40,242（昭 26); 日本臨床, 9(4),69（昭26）

4）前川孫二郎，他：生物物理化学，1（2）113（昭 27)

5) Stern, K. G., Reiner, M. \& Silber, R. H. : J. Biol. Chem., 161, 731 (1945)

6) Werzberg, A.: Folia haematol., 11, 17 (1911)

7) Alder, A., \& Huber, E.: Folia haematol., 29, 1 (1923)

8) Wintrobe, M. M. : Clinical haematol. II, 818 (1949)

9) Wintrobe, M. M.: Folia haematol., 51, 32 (1, 933)

10）沼野井春雄：動物の血液，生物学集書， 3,40（昭 22)

11) Ponder, E.; Hemolysis and related phenomena 122 (1948)

12) Ponder, E.: ibd., 123 (1948)

13) Ponder, E.: ibd., 127 (1948)

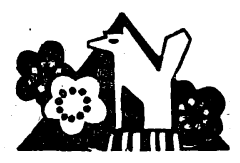

